\title{
THE IMPLEMENTATION OF SIMPLE PRESENT VERB AND VOCABULARY MASTERY ON STUDENTS' WRITING SKILLS IN PROCEDURE TEXT
}

\author{
Nuhra M. Saleh ${ }^{1}$ \\ Muhammad Sulhan ${ }^{2}$ \\ English Education Program, Postgraduate Faculty \\ Universitas Indraprasta PGRI \\ email: nuhrasyamy@gmail.com ${ }^{1}$ \\ email: muhammad.sulhan@unindra.ac.id ${ }^{2}$
}

\begin{abstract}
This research is a kind of survey and aims to determine the effects of simple present verb and vocabulary mastery on students' writing skills in procedure text. This research has three variables which are divided into two independent variables and one dependent variable. Test scores do the collection of the data for independent and dependent variables. The gained data were then analyzed by using the multiple regressions method. The results of this research are: 1) There are significant effects of simple present verb and vocabulary mastery towards students' writing skills in procedure text. It is proved by Sig. $=0.000<0.05$ and $\mathrm{F}_{\text {observed }}=12.541$; 2) There is a significant effect of simple present verb towards students' writing skill in procedure text. It is proved by Sig.= $0.000<0.05$ and $t_{\text {observed }}=2.041 ; 3$ ) There is a significant effect of vocabulary mastery towards students' writing skills in procedure text. It is proved by Sig. $=0.000<0.05$ and $\mathrm{t}_{\text {observed }}=2.201$.
\end{abstract}

Keywords: simple present verb, vocabulary mastery, procedure English text

\section{Introduction}

Language people can communicate, interact, convey their messages to their community and achieve their target. In this world, there are many languages, but the important one is English. As we know, English is the one of the important that has to be known by all people because English is an international language that people in the world have admitted. In Indonesia, English has functioned as a lingua Franca. It means that two different people from different countries use the language to communicate.

In Indonesia, English has been established as one of the subjects in formal education. From the basic level to advance level, from primary to secondary school, either only as an extracurricular subject or (compulsory) subject, English has been taught to all levels of education because English is significant to be learned and known. Therefore, our government, particularly the Minister of Educational, decided to put English as one of the crucial subjects in the school. The function of English in Indonesia is still considered a foreign language. So, many people, especially students, learn English but rarely use it. They use their mother tongue as a tool of communication to their community in daily life.

Teaching English should deal with four skills: reading, writing, speaking and listening. For students who are studying language, writing is one of the skills which have to be learned and considered as the most important thing, because it can influence other language skills (speaking, listening and reading). Speaking and writing are usually called productive skills, while listening and reading are called receptive skills.

Writing skill is one of the language skills that taught to students. It is based on the standard of graduate competency, stated in Kepmendiknas No. 23/2006, in the writing skill, the graduate of senior high school must be able to write short written functional text and simple essay in the forms of recount, narrative, procedure, descriptive, news item, report, analytical exposition, spoof, explanation, discussion, and review in the daily life content. The writer focuses on students' writing in procedure text. So, in this situation, 


\section{INFERENCE: Journal of English Language Teaching}

Vol. 4, No. 2, August-November 2021

p-ISSN: 2615-8671

e-ISSN: 2615-868X

teacher should try hard to encourage the students reach the purpose of English learning, especially in writing.

Writing is vital for the students because, in writing, the students need to learn writing in order to be able to express their ideas, thoughts, and feelings in the best possible ways on the page. There are several reasons as the basis of why students should master writing. First, effective communication can take place through the medium of writing. It means that writing can be a means of communication. Second, academic writing is emphasized on much greater accuracy and formal language that the students can use to reach their information levels.

Many people think writing is an easy skill than the other skills (reading, listening and speaking), but writing is one of the complex skills to study. Sometimes, people think writing skills are challenging because many factors influence writing, like vocabulary mastery, grammar, and ideas, and they need to know the comprehension of writing. Through writing, studying new words, we can get much knowledge, comprehend new ideas, study how the words are used, gain the knowledge, and implement the grammatical rules.

Writing is a communication process. It is an integral part of the skill in English, which should be emphasized in the teaching-learning process in the classroom but somewhat challenging to be developed. Many students think that writing is considered the most challenging skill. As a result, their writing ability is far from what is expected. The difficulty of writing involves vocabulary, knowledge, punctuation, spelling of words, arranging words in sentences, and less idea. The other difficulty students face the lack of grammar students have to be concerned about grammar rules because they will find it to communicate effectively in English, either spoken or written.

The students cannot write well if they do not have good grammar competence and vocabulary mastery. It happened because they have a lack of vocabulary that makes them feel hard to write. Then, the students sometimes get stuck to develop in their writing if they have not enough vocabulary. On the contrary, students who have good grammar and vocabulary mastery could be more confident than those who are not because they know how to make good and proper sentences.

And then, to make writing meaningful, one crucial component that should be correctly is used is grammar. Many students think writing is difficult because writing combines many aspects like grammar, vocabulary, and spelling. However, the students get problems and confuse in using grammar properly, especially in constructing words into sentences.

Brown (2001) argues that grammar competence as a significant communication component has an important position and tenses, which are considered the most difficult skills to learn for Indonesian students. The learner should combine some parts of grammar in tenses, like subject, verbs, pronoun, auxiliary verb articles, objects, adjectives, and adverbs.

When students know and understand the grammatical structure in writing, other people will easily understand their writing content. The messages, ideas, or information will be delivered correctly and meaningfully. So, their target in writing will achieve.

In writing, not only the grammatical structure but the other important aspect too is vocabulary mastery. Vocabulary mastery is one of the essential language components in studying English, especially in writing. Students will be confused in writing if they don't have enough vocabulary, although they have good ideas and know the grammatical structure. So, the students should have enough vocabulary and good grammatical structure to prove their writing.

To enable students to master the language skills, English teachers should provide appropriate material to the curriculum in the teaching and learning process. They should be able to apply knowledge and genre they have learned, especially in writing Procedure text. Procedure text is one of the genres that must be taught in senior high school.

For years and years of learning English, some students still have problems with their writing. Looking on the fact, students are still confused in writing in a procedure text due to ungrammatical English and less vocabulary they have. So, in this case the learners have not been successful yet.

The problem in generating the procedure text could be a boomerang for their writing task. However, to compose a procedure text effectively, one should know well about the procedure or step-by-step activities that should be followed. Many ways can be adopted to write a procedure text; one of them is by mastering grammar. A good procedure text is the structure of the sentence comprehensively covering the sentences' 
patterns and the good order of the sequence of the sentence. On the other hand, the students have to know the characteristic of procedure text.

Writing procedure text is a part of the recent target in teaching English for senior high school students. Based on the experience while joining the working experience in the senior high school, the writer observed many Senior High School students have difficulties in writing procedure text. Sometimes, students get confused to arrange their ideas when they want to write something, many students seem bored when the teacher asks them to write because they do not have enough vocabulary, some of the students have un-correct grammar, especially in using a simple present verb and have many mistakes in using the verb in the simple present especially in procedure writing, they often felt confused how to write the English word correctly, and they do not know the elements of procedure text. Especially when they want to use sequence in their sentence, writing an English word is different from how to pronounce it.

From the fact above, the writer wants to know the effect of simple present verb and vocabulary mastery in students writing procedure text. Therefore, the writer will specify this research on simple present and vocabulary mastery in teaching students' writing and focus on procedure text. The class of the research will be the Senior High School in South Tangerang.

\section{Definition of writing}

One of the most critical components in English is writing. Writing is the written productive language ability. It can communicate information or ideas to readers or groups of readers, especially in the teaching and learning process. The students and the teachers spend most of their time teaching and learning or writing. Writing well is not an inborn skill; it is usually learned through a set of instructional practices. It involves formulating new ideas and transforming information, which by itself is a complex process.

Writing has a much different meaning. According to Mayers (2005:21) stated that" writing is a way to communicate to others through paper or a computer screen. writing is a kind of talent. However, it is primarily a skill, it improves with practice like another skill".

\section{Definition of Procedure}

The procedure is a kind of genre used to describe how something is accomplished through a sequence of actions or steps. Soeprapto and Darwis (2007:45) stated that Procedure text is a text to describe something that is accomplished roughly by a sequence of actions or steps. Procedure text is a text has shown a process in order. According to Zaida (2018), the Procedure text explains how people make or do something step by step.

\section{Definition of the simple present verb}

Azar (2003:11) stated that the simple present was actual in the present and will be confirmed in the future. The simple present is used to express the habitual or everybody activity. It is used for the general statement of the fact. The simple present may indicate the situation that exists right now, at the moment of speaking, for example: (1) She always eats fried rice for breakfast, (2) The world is round. So, the function of a simple present is to show something or activity when the activity is a general truth. Besides that, a simple present can show the habitual or daily activity, and something that happens at the time of speaking. According to Walker \& Elsworth (2005:34), the ending of she, he, and it if the verb ends in ss, sh, ch or $x$ add $e s$. For example, 'He finishes' (finish end in $s h$ ), She watches (watch end in $c h$ ). Use for permanently actual like: I come from France, He doesn't speak English, and We live in London. Besides, I don't see them very often for repeated actions or habits like: I get up at six o'clock every day.

From the explanation above, when making a simple present sentence, you should know about the subjects/pronoun, what verb should follow it, and remember the last word of the verb and its correct answer.

\section{Definition of vocabulary mastery}

Napa (1999) stated that Vocabulary mastery is competence or complete knowledge of a list or set of words that make up a language that might be used by a particular person, class, or profession. It means that vocabulary mastery is one component to master English as a foreign language.

The goal of vocabulary mastery is to build students' vocabulary by helping them learn about a new word or expression. In writing skills, vocabulary mastery can be defined as several vocabulary or words in the memory of users or learners. It can be simplified the meaning of certain words. In other words, it is 


\section{INFERENCE: Journal of English Language Teaching}

Vol. 4, No. 2, August-November 2021

p-ISSN: 2615-8671

e-ISSN: 2615-868X

more precisely defined as "to know a word" because the learners are said to have a good vocabulary mastery if they are able to recognize the meaning but also to know form, grammar, collocation, meaning and word formation.

\section{Method}

The method of this research used in this thesis is the survey method. Survey research is used because there is a supported hypothesis in advance, and the writer did not do any treatments. Correlation analysis is carried out because it will be found the effect of one variable and the other variables. This research will know the effect of variables simple present verb and vocabulary mastery on students' writing in procedure text.

The data will be interpreted to descriptive analysis. The descriptive approach can be used by collecting data or information as much as possible about the mastery of simple present verbs and vocabulary mastery on students' writing in procedure text. Then write the analyzed result of students' performance about procedure text. This research is emphasized on the effect of simple present verbs and vocabulary mastery on students' writing in procedure text.

The researcher finds out on the data to collect the data, namely students' simple present verb, vocabulary Mastery, and vocabulary Mastery. The data are collected by giving an objective test for independent variables; there will be 30 numbers of multiple-choice questions. A set of written tests for dependent variables use for indicators there are content, coherence, grammar, and vocabulary.

\section{Results and Discussion}

\section{A. Description of Data}

1) The Data of Writing in Skill in Procedure Text (Y)

The data of writing skill in procedure text was obtained from 60 students as the result samples. Based on the following table, the minimum score is 65 , and the maximum score is 95 , the mean is 80.58 , the median is 80.00 , the mode is 80 and 6.833 for the standard deviation.

Table 1

The Description Data of writing Skill in Procedure Text

\begin{tabular}{|c|c|c|}
\hline \multicolumn{3}{|c|}{ Statistics } \\
\hline \multicolumn{2}{|c|}{ Students' Writing in Procedure Text } \\
\hline \multirow{2}{*}{$\mathrm{N}$} & Valid & 60 \\
\cline { 2 - 3 } & Missing & 0 \\
\hline \multicolumn{2}{|c|}{ Mean } & 80.58 \\
\hline \multicolumn{2}{|c|}{ Median } & 80.00 \\
\hline \multicolumn{2}{|c|}{ Mode } & 80 \\
\hline \multicolumn{2}{|c|}{ Std. Deviation } & 6.833 \\
\hline \multicolumn{2}{|c|}{ Minimum } & 65 \\
\hline \multicolumn{2}{|c|}{ Maximum } & 95 \\
\hline
\end{tabular}

From the calculation above, it can be said that the students' writing skill in procedure text at state senior high school in South Tangerang is good. It is indicated by the mean score, which is 80.58 . Furthermore, to know it clearly, the description data is drawn in Figure 1: 


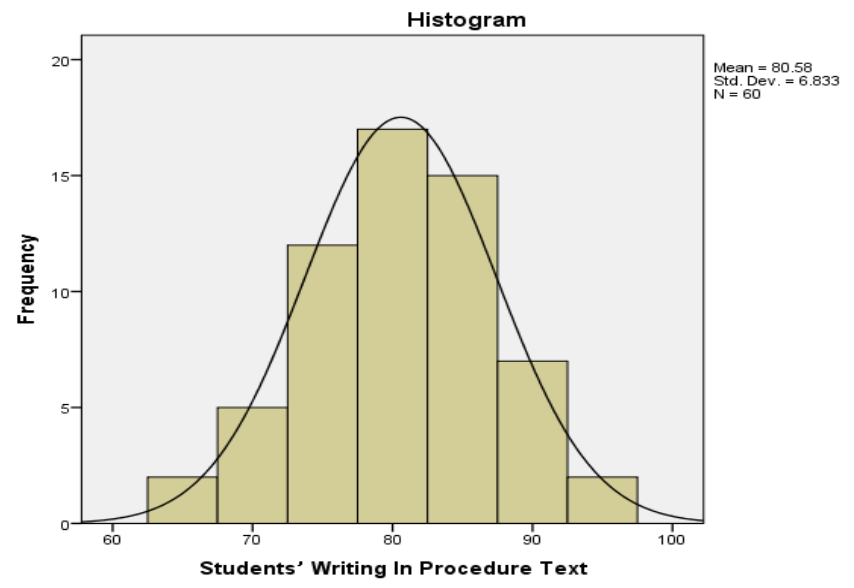

Figure 1. Histogram Polygon Variable: Student's writing procedure text

From the histogram as well as the polygon frequency, It can be concluded that the data score of the students writing skills in procedure text at state senior high school in south Tangerang has a normal distribution.

\section{2) The Data of Simple Present Verb $\left(X_{I}\right)$}

The data of simple present verb was obtained from 60 students as the result samples. There are 30 questions given as the instrument of vocabulary mastery. Based on the following table, the minimum score is 65 , and the maximum score is 95 , the mean is 80.58 , the median is 80.00 , the mode is 80 , while the standard deviation is 6.833 .

Table 2

The Description Data of Simple Present Verb

\begin{tabular}{|c|c|c|}
\hline \multicolumn{3}{|c|}{ Statistics } \\
\hline \multicolumn{3}{|c|}{ Simple Present Verb } \\
\hline \multirow{2}{*}{$\mathrm{N}$} & Valid & 60 \\
\hline & Missing & 0 \\
\hline & Mean & 78.02 \\
\hline & Median & 79.00 \\
\hline & Mode & 76 \\
\hline & Std. Deviation & 8.290 \\
\hline & Minimum & 46 \\
\hline & Maximum & 94 \\
\hline
\end{tabular}

From the calculation above, it can be said that the students' simple present verb at state senior high schools in South Tangerang is moderate. It is indicated by the mean score, which is 78.02. Furthermore, to know it clearly, the data description is drawn in Figure 2. From the histogram and polygon frequency, it can be concluded that the data score of the students' simple present verb at senior high schools in South Tangerang has a normal distribution. 


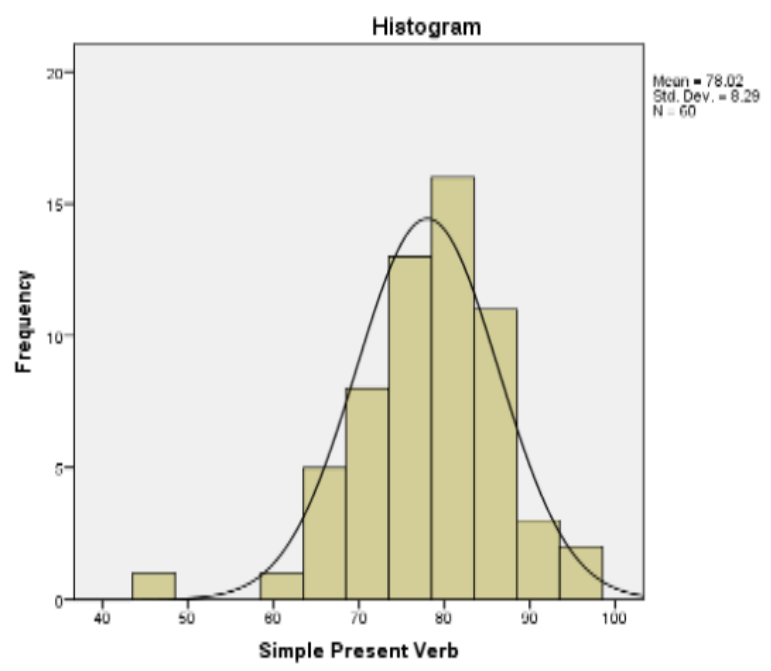

Figure 2. The Histogram Polygon Variable of Simple present verb

\section{3) The Data of Vocabulary Mastery $\left(X_{2}\right)$}

The data of vocabulary mastery was obtained from 60 students as the result samples. Based on the following table, the minimum score is 70 , and the maximal score is 94 , the mean is 79.73 , the median is 79.00, the mode is 79, and the standard deviation is 5.923 .

Table 3

The Data Description of Vocabulary Mastery

\begin{tabular}{|c|c|c|}
\hline \multicolumn{3}{|c|}{ Statistics } \\
\hline \multicolumn{3}{|c|}{ Vocabulary Mastery } \\
\hline \multirow{2}{*}{$\mathrm{N}$} & Valid & 60 \\
\cline { 2 - 3 } & Missing & 0 \\
\hline Mean & 79.73 \\
\hline Median & 79.00 \\
\hline Mode & 79 \\
\hline Std. Deviation & 5.923 \\
\hline Minimum & 70 \\
\hline \multicolumn{2}{|c|}{ Maximum } & 94 \\
\hline
\end{tabular}

From the calculation above, it can be said that students' vocabulary mastery in a senior high school in South Tangerang is moderate. It can be seen by the mean score, which is 79.73 . Furthermore, to know it clearly, the data description is drawn into the following diagram:

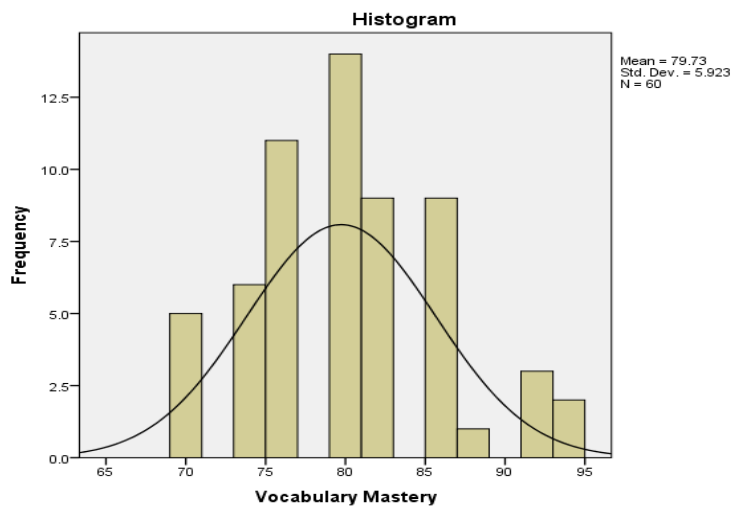

Figure 3. The Histogram and Polygon of Vocabulary Mastery 
From the above histogram and polygon frequency, it can be concluded that the data score of students' vocabulary mastery at senior high schools in South Tangerang has a normal distribution.

4) The Effect of Simple Present Verb (X1) and vocabulary Mastery (X2) Jointly towards Students' Writing Skill in Procedure Text $(Y)$.

Tested Hypothesis

$$
\begin{gathered}
H_{0}: \beta_{y 1}=\beta_{y 2}=0 \\
H_{1}: \beta_{y 1} \neq 0, \beta_{y 2} \neq 0
\end{gathered}
$$

1. Ho $=$ There is no significant effect of simple present verb and vocabulary mastery towards students' writing skills in procedure text.

2. $\mathrm{H} 1=$ There are no significant effects of simple present verb and vocabulary mastery on students' writing skills in procedure text.

Table 2 shows the significant effects of simple present verb and vocabulary mastery on students' writing skills in procedure text. It is proved by the output score of Sig $=0.000<0.05$ and $\mathrm{F}_{\mathrm{H}}=12.541$. In addition, Table 3 shows the double regression line equation of $\widehat{Y}=32,582+0,243 \mathrm{X}_{1}+0,365 \mathrm{X}_{2}$. It means that every increase of 1 score of the simple present verb can improve the students' writing skill in procedure text for 0.243 , and every increase of 1 score of vocabulary mastery improves the students' writing skill in procedure text for 0.365 . Table 2 also shows that simple present verb and vocabulary mastery jointly have given the contribution of $30,6 \%$ towards students' writing skills in procedure text.

5) The Effect of Simple Present verb (X1) towards Students' Writing Skill in Procedure Text (Y).

Tested Hypothesis

$$
\begin{aligned}
& H_{0}: \beta_{y 1}=0 \\
& H_{1}: \beta_{y 1} \neq 0
\end{aligned}
$$

1. Ho $=$ There is a significant effect of simple present verbs on students' writing skills in procedure text.

2. $\mathrm{H} 1=$ There is a significant effect of simple present verbs on students' writing skills in procedure text.

Table 3 shows a significant effect of simple present verb mastery towards students' writing skills in procedure text. It is proved by the output score of $\mathrm{Sig}=0.045<0.05$ and to $=2.049$. The contribution of simple present verb variable towards the variable of students' writing skill in procedure text. It can be started in the following formula:

$$
\begin{gathered}
\mathrm{KD}=\text { value of } \beta_{x 1 y} \text { the } \mathrm{x} \text { value of partial correlation }\left(r_{x 1 y}\right) \times 100 \% \\
\mathrm{KD}=0,294 \times 0,497 \times 100 \%=14,61 \%
\end{gathered}
$$

According to the calculation above, a simple present verb contributes $14,61 \%$ towards the increase of students' writing skills in procedure text.

6) The Effect of Vocabulary Mastery (X2) towards Students' Writing Skill in Procedure Text (Y).

Tested Hypothesis

$$
\begin{aligned}
& H_{0}: \beta_{y 2}=0 \\
& H_{1}: \beta_{y 2} \neq 0
\end{aligned}
$$

1. Ho $=$ There is no significant effect of vocabulary mastery on students' writing skills in procedure text. 


\section{INFERENCE: Journal of English Language Teaching}

Vol. 4, No. 2, August-November 2021

p-ISSN: 2615-8671

e-ISSN: 2615-868X

2. H1 = There are no significant effects of vocabulary mastery on students' writing skills in procedure text.

Table 3 shows a significant effect of vocabulary mastery on students' writing skills in procedure text. It is proved by the output score of $\mathrm{Sig}=0,032<0,05$ and $\mathrm{t}_{\mathrm{h}}=2,201$. The contribution of vocabulary mastery variable towards the variable of students' writing skill in procedure text. It can be started in the following formula:

$$
\begin{aligned}
& \mathrm{KD}=\text { value of } \beta_{x 2 y} \text { the } \mathrm{x} \text { value of partial correlation }\left(r_{x 2 y}\right) \times 100 \% \\
& \mathrm{KD}=0,316 \times 0,504 \times 100 \%=15,93 \%
\end{aligned}
$$

\section{Conclusions}

There are no significant effects of Simple present verb and vocabulary mastery on students' writing skills in procedure text at state senior high schools in South Tangerang. That is proved by the sig.0,000 < 0,005 and the value of $\mathrm{F}$ observed $=12.541$; the output also shows the two independent variables of the simple present verb and vocabulary mastery jointly have given a contribution of $30.6 \%$ towards the variable of students' writing skill in procedure text. Second, there is a significant effect of Simple present verb mastery towards student's writing skills in procedure text at state senior high schools in South Tangerang. That is proved by sig $0,045<0,05$ and to $=2.049$. The variable of the simple present gives a contribution of $14.61 \%$ in increasing student's writing skills in procedure text. Third, there is a significant effect of vocabulary mastery on students' writing skills in procedure text at state senior high schools in South Tangerang, proved by Sig $0,032<0,05$ and to $=2.201$. The variable of vocabulary mastery contribution of $15.93 \%$ in increasing student's writing skill in procedure text.

\section{References}

Allen, D. (2000). Microteaching. Massachusetts: Addison-Wesley Publishing Company.

Allen, R. (2000). The New Penguin English Dictionary. London: Penguin Books: www. Seyfinoca.Com.

Ansel, M. (2000). Free English Grammar. Seyfihoca: www. Seyfihoca.Com.

Azar, B. S (2002). Understanding and using English grammar. New York: Pearson Education.

Azar, B. S (2002). Fundamentals of English Grammar English Grammar (Third Edition). New York: Pearson Education.

Brown, H. D. (2001). Teaching by Principle and Interactive Approach to Language Pedagogy. England: Longman.

Brown, H. D. (2004). Language Assessment Principle and Classroom Practices. England: Longman.

Carter, R. \& McCarthy, M. (2006). "Cambridge Grammar of English. Cambridge University Press.

Glynn, T., Wearmouth, J., \& Berryman, M. (2006). Supporting Students with Literacy Difficulties. USA: Open University Press.

Gruyter, M.D. (2006). The Grammar of the English Tense System. A Comprehensive Analysis Belgium: Leuven University.

Harmer, J. (2007). How to Teach Writing. Essex. Person Education Limited.

Hartono, R. (2005). Genres of Text, Semarang: UNNES.

Hyland, K. (2003). Writing and Teaching Writing, In J. C. Richard (Ed.), Second Language Writing. Cambridge: Cambridge University Press.

Hyland, K. (2004). Genre and Second Language Writing. Michigan: The University of Michigan Press.

Jackson, Howard. (2003). Good Grammar for Students. London: Sage Publication.

Linse, C. T. (2005). Practical English Young Learners. New York: Cambridge University Press.

Mayers, A. (2005). Gateways to Academic Writing: Effective Sentences Paragraph and Essays. New York: Longman.

Napa, A. P. (1994). Vocabulary Development Skill. Kanisius. Yogyakarta.

Nation, I. S. P. (2009). Teaching ESL/EFL Reading and Writing. New York: Routledge Publishers.

Penston, T. (2005). A Concise Grammar for English Language Teachers. ------. T.P. Publication.

Renkema, J. (2003). Introduction to Discourse Studies. USA Jhon Benjamins Publishing Company. 
INFERENCE: Journal of English Language Teaching

Vol. 4, No. 2, August-November 2021

p-ISSN: 2615-8671

e-ISSN: 2615-868X

Rumisek, L.A. \& Zemach, D. E. (2005). Academic Writing: from Paragraph to Essay. Oxford: Macmillan Publisher.

Shiffrin, D. (2003). Approaches to Discourse. The USA. Blackwell Publishers Inc.

Seely, J. (2012). Grammar for Teacher. The United Kingdom. Oxpecker.

Simon, P. (2016). The Grammaring Guide to English Grammar with Exercise (second Edition). English Peter Simon.

Soeprapto, F. A. \& Darwis, M. (2006). Linked to the World 1 English for Senior High School (second Edition). Perpustakaan Nasional. Jakarta.

Sugiyono. (2012). Metode penelitian pendidikan: pendekatan kuantitatif, kualitatif, dan R\&D. Bandung: Alfabeta.

Thornbury, S. (2002). How to Teach Vocabulary. Pearson Education Limited.

Walker, E \& Elsworth, S. (2000). Grammar Practice. Edinburgh: Longman.

Wiggins, G. (2013). How good is good enough? (Cover story). Educational Leadership, 71(4),10. 